\title{
An overview of the crisis of the rule of law in Africa
}

\section{Charles Manga Fombad*}

Professor of Law, Institute for International and Comparative Law in Africa, Faculty of Law, University of Pretoria, South Africa

\section{Summary}

After the wave of democratic and constitutional reforms in the 1990s, the rule of law appeared to have enjoyed a revival in Africa. Apparently there were strong constitutional commitments by African countries for respect for the rule of law, backed by the signature and ratification of international and regional treaties imposing this obligation. However, the last two decades have seen a steady weakening of this commitment. It is argued that developing an appropriate strategy for dealing with the persistent, systemic and systematic threats to the rule of law in Africa requires an understanding of the nature and extent of the crisis. The critical question is whether the proper tools are available at national and continental level to monitor and deal with these threats. After exploring the meaning and scope of the concept of the rule of law, this article, guided by a number of regional and international indicators, assesses the extent of Africa's rule of law problems. It then examines the various options for facilitating systematic monitoring of the enforcement of rule of law standards. Based on the approach adopted by the Council of Europe and the European Union, it is argued that the African Union and regional economic communities must develop a well thought-out strategy within the existing normative frameworks to address the present problems of systemic threats to and persistent breaches of the rule of law.

Key words: constitutionalism; democracy; human rights; rule of law

\section{Introduction}

The rule of law, generally regarded as essential to modern constitutional democracy, appeared to have enjoyed a revival in Africa during the so-called 'third wave' of democratisation in the 1990s.

* Licence-en-Droit (Yaoundé) LLM PhD (London); charles.fombad@up.ac.za 
There were promising signs that the days of repressive military or oneparty dictatorship were over and that a new era of governance had been ushered in, one guided by the principles of constitutionalism, democracy, good governance and rule of law. However, despite the commitment by African states to respect the rule of law - a commitment which is evident in their constitutions and in their signature and ratification of international and regional instruments imposing this obligation - the last decade has seen this commitment steadily weaken. Today, there is growing uncertainty as to whether the post-1990 constitutions indeed can enable the continent to avoid a resurgence of authoritarianism.

The maintenance of the rule of law is of critical importance: It is the bedrock on which the democracy and democratic practices needed for political stability and economic growth are founded. In spite of the euphoria of the early 1990s, presently too many countries, such as Burundi, the Democratic Republic of the Congo (DRC), Somalia and South Sudan, are in turmoil. It may be argued that the crisis around the rule of law is at the heart of many of Africa's present developmental predicaments, such as political instability, economic decline, poverty, unemployment and endemic corruption. Therefore, it is imperative to develop effective strategies to deal with this problem. However, developing an appropriate strategy for dealing with the persistent, systemic and systematic threats to the rule of law in Africa requires an understanding of the nature and extent of the crisis. There are also questions as to whether the proper tools are available at national and continental level to monitor and deal with these threats.

The article is divided into five sections, including this introduction. The second section considers the meaning and scope of the concept of the rule of law. The third assesses the extent of Africa's rule of law problems by examining a number of regional and international indicators. Section four looks at the various options for facilitating the systematic monitoring of the enforcement of rule of law standards in Africa. The concluding remarks emphasise that there is no room for complacency, given the overwhelming evidence of a decline in respect for the rule of law in almost all African countries, including those that in the past were hailed for their performance in promoting constitutionalism, democracy, good governance and respect for the rule of law. It is, therefore, argued that the African Union (AU) and regional economic communities (RECs) must develop a well-thoughtout strategy within the existing normative frameworks to address all cases of systemic threats or serious and persistent breaches of the rule of law.

First, what do we mean by the rule of law and what is its scope? 


\section{Meaning and scope of the rule of law}

The rule of law, for reasons which will become obvious, has been described as a 'contested concept' or as 'work in progress'. 1 Whilst the concept is usually associated with the famous English constitutional scholar Dicey, ${ }^{2}$ the idea goes back as far as Aristotle. ${ }^{3}$ However, the modern concept has been influenced by other legal doctrines, such as the German Rechtsstaat, the French Etat de droit and developments in international law. ${ }^{4}$

The effective enforcement of the rule of law depends on clarity about what it means and its fundamental features, nature and scope. Is there such clarity? While there is consensus that the rule of law is one of the most important bulwarks against dictatorship and arbitrary governance, divergent views exist on the exact meaning of the concept. This is surprising given that the obligation to comply with the rule of law has become 'a global ideal and aspiration', 5 one that appears not only in national constitutions but in many international instruments, for example the Preamble to the Universal Declaration of Human Rights (Universal Declaration). ${ }^{6}$ The need for universal adherence to the rule of law at both national and international levels was endorsed by all the members of the United Nations (UN) in the 2005 Outcome Document of the World Summit. ${ }^{7}$

At the regional level, there are references to the rule of law in at least two important documents of the AU. The Preamble to the 2002 Constitutive Act of the $\mathrm{AU}$ underlines 'the determination of the member states to promote and protect human and peoples' rights, consolidate democratic institutions and culture, and to ensure good governance and the rule of law'. In article $4(\mathrm{~m})$, it goes on to state as one of its fundamental principles the 'respect for democratic principles, human rights, the rule of law and good governance'. The 2012 African Charter on Democracy, Elections and Governance (African Democracy Charter) elaborates even further. In its Preamble, the member states reiterate their 'collective will to work relentlessly to

1 See Bingham Centre for the Rule of Law 'Short course: Introduction to the rule of law', https://www.biicl.org/documents/1297_introduction_to_the_rule_of_law_ programme_1.pdf?showdocument=1 (accessed 30 June 2017).

2 See AV Dicey An introduction to the study of the law of the constitution (1945) 188.

3 See T Bingham The rule of law (2010) 3.

4 See generally P Costa \& D Zolo The rule of law history, theory and criticism (2007).

5 See R Janse Rule of law. A guide for politicians (2012) 6.

6 The Preamble states, inter alia, that '[w] hereas it is essential, if man is not to be compelled to have recourse, as a last resort, to rebellion against tyranny and oppression, that human rights should be protected by the rule of law'.

7 Clause 11 of the final resolution states: 'We acknowledge that good governance and the rule of law at the national and international levels are essential for sustained economic growth, sustainable development and the eradication of poverty and hunger.' The rule of law is also mentioned in clauses 16, 21, 24(b) and 25(a), and human rights and the rule of law are highlighted as one of the four priority areas for action in Part 1V and clause 34. 
deepen and consolidate the rule of law, peace, security and development'. In article 2(2) the Democracy Charter states as one of its objectives the desire to 'promote and enhance adherence to the principle of the rule of law premised upon the respect for, and the supremacy of, the Constitution and constitutional order in the political arrangements of the state parties'. It devotes the whole of chapter 4 to 'democracy, rule of law and human rights'. Article 32 calls on state parties to strive to institutionalise good political governance through 'entrenching and respecting the principle of the rule of law'.

It is clear not only from these UN and African instruments but other regional instruments ${ }^{8}$ that there is an international consensus that the rule of law is a fundamental concept of universal application. The global recognition of the rule of law as an important principle of modern constitutional governance is underscored by its explicit recognition in the constitutions of at least 23 African countries. ${ }^{9}$ This raises the question of whether those countries whose constitutions do not expressly, or only implicitly, entrench the concept in their constitutions are bound to comply with the imperatives of the rule of law. The answer will depend on the meaning and scope of this concept. In this regard, it is particularly conspicuous that no provision in any of these international instruments or in the national constitutions that refer to the rule of law makes any serious attempt to define the concept. This is not surprising, as the rule of law is notoriously difficult to define, let alone measure. As Bingham has rightly pointed out, this is no reason to conclude that the concept is 'too uncertain and subjective ... to be meaningful'. 10

There probably are as many definitions of the concept as there are writers on the subject. Although Dicey is regarded as having coined the expression 'rule of law', his threefold definition of the concept is fairly outdated. ${ }^{11}$ After analysing definitions proposed by various

8 For the position under other regional instruments, see the European Commission for Democracy through Law (Venice Commission) Rule of Law Checklist, adopted by the Venice Commission in 2016 (Venice Commission Rule of Law Checklist), http://www.venice.coe.int/webforms/documents/default.aspx?pdffile=CDL-AD (2016)007-e (accessed 30 June 2017).

9 See the Constitutions of Algeria (Preamble and art 203); Angola (arts 2, 6, 11, 129, 174, 193, 202, 211, 212 \& 236); Cameroon (Preamble); Cape Verde (Preamble and arts 2 \& 7); Central African Republic (Preamble and art 18); Chad (Preamble); Comoros (Preamble); Egypt (arts 1, 94, 198 and the whole of chapter 4); Ethiopia (Preamble and art 52); Madagascar (Preamble, arts 1, 43, 107, 112, 113, 118 \& 136); Gabon (art 9); The Gambia (sec 60); Ghana (Preamble and art 36), Kenya (Preamble, arts 10, 91, 146, 238 \& 258); Lesotho (sec 154); Namibia (art 1); Nigeria (sec 315); Rwanda (Preamble and art 10); Senegal (Preamble); South Africa (sec 1); South Sudan (Preamble, secs 46, 48, 125, 151, 156, 157 \& 159); Tanzania (Preamble, arts 1, 6, 8 \& 265); and Zimbabwe (Preamble, arts 3, $90,114,164,165 \& 206)$.

10 See Bingham (n 3 above) 6.

11 These may be summarised as follows: first, the principle of legality; and, second, the principle of equality of all before the law. The third component of the definition is a dismissive reference to foreign constitutions and the role of administrative courts. See further Dicey (n 2 above) 188-196. 
authors from different systems of law and state organisations as well as diverse legal cultures, the Venice Commission concludes that the notion of the rule of law

requires a system of certain and foreseeable law, where everyone has the right to be treated by all decision-makers with dignity, equality and rationality and in accordance with the laws, and to have the opportunity to challenge decisions before independent and impartial courts through fair procedures. $^{12}$

The World Justice Project, which describes itself as 'the world's leading source for original, independent data on the rule of law', uses what it refers to as 'a working definition of the rule of law based on four universal principles, derived from internationally accepted standards'.13

For our purposes, what could be considered as the most widelyaccepted modern conceptualisation of the rule of law was formulated by the UN Secretary-General in 2004. This UN formulation defines the rule of law as

a principle of governance in which all persons, institutions and entities, public and private, including the state itself, are accountable to laws that are publicly promulgated, equally enforced and independently adjudicated, and which are consistent with international human rights norms and standards'. It also points out that as a principle, the rule of law ... requires, as well, measures to ensure adherence to the principles of supremacy of law, equality before the law, accountability to the law, fairness of the law, separation of powers, participation in decision-making, legal certainty, avoidance of arbitrariness and procedural and legal transparency.

In spite of the differences of opinion over its precise definition and nature, there is now reasonable consensus about what could be considered to be the core elements of the rule of law. These consist of the following:

(i) the principle of legality, which includes the requirement of a transparent, accountable and democratic process for enacting laws;

12 See Venice Commission Rule of Law Checklist (n 8 above) 6.

13 These are stated as follows: '(i) The government and its officials and agents as well as individuals and private entities are accountable under the law. (ii) The laws are clear, publicised, stable and just; are applied evenly; and protect fundamental rights, including the security of persons and property. (iii) The process by which the laws are enacted, administered, and enforced is accessible, fair and efficient. (iv) Justice is delivered in a timely manner by competent, ethical, and independent representatives and neutral parties who are of sufficient number, have adequate resources and reflect the make-up of the communities they serve.' See World Justice Project Rule of Law Index 2016 9, http://data.worldjusticeproject.org/ (accessed 30 June 2017).

14 See Report of the Secretary-General 'The Rule of Law and Transitional Justice in Conflict and Post-conflict societies' http://www.google.com/url?sa=t\&rct=j\&q=

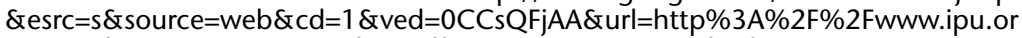
g\%2Fsplz-e\%2Funga07\%2Flaw.pdf\&ei=IHODUri_NM-QhQfv04HoBQ\&usg=AFQj CNH4tfk4EZdh3/ZfJalOMTylL777RA\&sig2=_51 SuV̄7GbBdRzWVgX16iNg\&bvm=bv $.56343320, \mathrm{~d} . Z \mathrm{ZG}$ (accessed 30 June 2017). 
(ii) the principle of non-discrimination and equality before the law, which means that government and its officials and agents as well as individuals and private entities are accountable under the law;

(iii) legal certainty and prohibition of arbitrariness, which requires that laws are clear, publicised, stable, and just, are applied evenly, and protect fundamental rights, including the security of persons and property;

(iv) the process whereby the laws are enacted, administered and enforced is accessible, fair and efficient;

(v) justice delivered in a timely manner by competent, ethical, and independent representatives and neutrals who are of sufficient number, have adequate resources, and reflect the make-up of the communities they serve; and

(vi) respect for human rights.

This list of core elements is not exhaustive, nor is it final and valid for all time. Nevertheless, it does provide a reasonably good indication of a global model the application of which is inevitably affected by each country's constitutional and legal traditions. In this broad sense, the rule of law can apply only in a liberal constitutional democracy. It is now necessary to examine the rule of law challenges in Africa in light of this broad understanding of the concept.

\section{Assessing the evidence of the rule of law crisis in Africa}

Assessing the state of the rule of law inevitably requires an evaluation of the extent of compliance with all or some of the core elements identified above. There is no generally-agreed universal standard for conducting such an assessment. Nevertheless, several international non-governmental organisations (NGOs) have attempted to develop indicators for evaluating and measuring compliance with one or more of these rule of law components. While most of these assessments have been global, some have focused on Africa. The evidence gathered by these bodies, at both international and regional levels, are now examined.

\subsection{International indicators of the rule of law crisis in Africa}

Several international surveys are regularly conducted to assess the performance of countries in one or more of the components of the rule of law. These include the World Justice Project, which focuses exclusively on the rule of law, as well as others, such as Freedom House (which carries out annual surveys and reports on freedom of the press, freedom of the world, and freedom on the internet); ${ }^{15}$

15 https://freedomhouse.org/reports (accessed 30 June 2017). 
Transparency International's annual Corruption Perception Index; ${ }^{16}$ and the fragile state index. ${ }^{17}$ This discussion will concern only three of these: the World Justice Project, Freedom House's freedom of the world and the fragile state index.

\subsubsection{Evidence based on the World Justice Project's Rule of Law Index}

The Rule of Law Index published by the World Justice Project since 2011 is the only such project devoted exclusively to the rule of law as broadly defined above. ${ }^{18}$ It provides scores and rankings for the rule of law in each country in respect of eight factors or themes: constraints on government powers; absence of corruption; open government; fundamental rights; order and security; regulatory enforcement; civil justice; and criminal justice. ${ }^{19}$ The factors are intended to reflect the way in which people experience the rule of law in their daily lives, thereby providing a basis for measuring a country's adherence to the rule of law. In this way, areas of strength and weakness are identified. The scores and rankings are based on 44 subfactors. ${ }^{20}$

Although the World Justice Project reports date back to 2006, it is only the analysis for the periods 2012/2013, 2014, 2015 and 2016 that provide some evidence of trends in Africa. The 2012/2013 report reveals that Africa lags behind other regions around the world in nearly all dimensions of the rule of law. ${ }^{21}$ Of the 18 African countries surveyed during this period, Botswana, Ghana and South Africa came out on top, whereas Nigeria, Cameroon and Zimbabwe were at the bottom. The same 18 countries were assessed in 2014 with the same results, namely, with Botswana, Ghana and South Africa being the overall top rule of law performers but with global rankings of twentyfifth, thirty-seventh and fortieth, respectively, showing that countries in the region still were not performing well. ${ }^{22}$ The same three countries, namely, Nigeria, Cameroon and Zimbabwe, were the weakest performers; their global ranking of ninety-third, ninety-fifth and ninety-seventh, respectively, from the 99 countries in the world reviewed underscores the problem around the rule of law in Africa. In 2015, 21 African countries were assessed out of 102 globally, and the

16 https://www.transparency.org/news/feature/corruption_perceptions_index_2016 (accessed 30 June 2017).

17 http://reliefweb.int/report/world/fragile-states-index-2016 (accessed 30 June 2017).

18 See generally World Justice Project Rule of Law Index 2016 (n 13 above).

19 A 9th factor, informal justice, is measured but not included in the aggregated scores and rankings.

20 For a detailed description of the processes and methodology of collecting data for the information, see World Justice Project Rule of Law Index 2016 (n 13 above).

21 https://worldjusticeproject.org/sites/default/files/documents/WJP_Index_Report 2012.pdf (accessed 30 June 2017).

22 https://worldjusticeproject.org/sites/default/files/files/wjp_rule_of_law_index_ 2014_report.pdf (accessed 30 June 2017). 
pattern of strong and weak rule of law performers in Africa remained exactly the same. ${ }^{23}$ The overall global performance of African countries showed a slight deterioration in rule of law performance. ${ }^{24}$

A recent report, based on 2016 data, shows that the same three countries were the strongest performers in Africa. Their global ranking, with South Africa ranked forty-third (a drop of seven positions), Ghana, forty-fourth (a drop of 10 positions) and Botswana, frty-fifth (a drop of 14 positions), points to an alarming drop in adherence to the rule of law in Africa. ${ }^{25}$ The decline in rule of law adherence is also evident amongst the group of poorly-performing countries. This consists of Egypt, ranked at one-hundred-and-tenth (a drop of 24 positions); Cameroon, at one-hundred-and-ninth (a drop of 12 positions), and Zimbabwe, at one-hundred-and-eighth (a drop of eight positions). Even if one takes into account that 113 as compared to 102 countries were surveyed in 2016, the deterioration is still dramatic and significant. ${ }^{26}$ Finally, it is also worth noting that for the two years during which the average regional rule of law rankings for each factor were assessed, Africa's poorest-performing areas for 2012/2013 were in civil justice, constraints on government and corruption. In the 2014 index, the lowest-performing area remained civil justice, followed by constraints on government and the state of criminal justice.

The first, and obvious, observation to be made is that respect for the rule of law in Africa has been progressively declining. The effective rule of law requires consistent compliance with its various component elements. The second observation is that of the 18 to 21 African countries that have been surveyed since the World Justice Project started, some countries have consistently performed well, such as Botswana, Ghana and South Africa, whereas others, such as Cameroon, Nigeria and Zimbabwe, have consistently shown low levels of adherence to the rule of law.

The next section deals with surveys that focus on one or more of the individual components the rule of law outlined above. It first

23 https://worldjusticeproject.org/sites/default/files/roli_2015_0.pdf

(accessed 30 June 2017).

24 Botswana was ranked 31st (a drop of six positions); Ghana, 34th (an improvement of 3 positions); and South Africa 36th (an improvement of four positions). In the case of the regularly underperforming countries, Nigeria is in 96th position (a drop of three positions); Cameroon in 95th position (a drop of two); and Zimbabwe in 100th position (a drop of three positions).

25 https://worldjusticeproject.org/sites/default/files/documents/RoLI_Final-Digital_0. pdf (accessed 30 June 2017).

26 The increase in numbers does not explain this as the scores themselves also show a remarkable decrease. Eg, Botswana scored 0,64 in 2015 but only 0,58 in 2016; Ghana scored 0,60 in 2015 but only 0,58 in 2016; and South Africa scored a mere 0,58 in 2015 and 0,59 in 2016, claiming the top spot in Africa. For the underperforming countries, the trend is similar. In 2016, Egypt, Cameroon and Zimbabwe all scored 0,37, but in 2015, Egypt scored 0,44 and Cameroon 0,40, while Zimbabwe had a similar score of 0,37 . 
attends to these specific components and thereafter provides an overall account of the performance of African states.

\subsubsection{Evidence based on the Freedom House Freedom in the World surveys}

Freedom House's Freedom in the World survey is a long-standing and widely-consulted annual survey on the state of political and civil rights around the world. It tracks the trends in 209 countries and territories and has been published regularly in its present comprehensive form since $1973 .{ }^{27}$ The Freedom of the World rating process uses a threetiered system consisting of scores, ratings and status. ${ }^{28}$ The scores are awarded to each country or territory based on 10 political rights indicators and 15 civil rights indicators.

To enable one to appreciate the evolving trends in political and civil rights, we extracted and analysed the scores for African countries from the global scores for three different periods. The first period, 19731982, arguably reflects the lowest point of constitutionalism and the peak of post-independence authoritarianism. The second period, 1991-2000, marks the beginning of democratic revival and a wave of constitutional modernisation. The final period, 2007-2017, is characterised by a decline.

Two observations may be made about the evolution of civil and political rights from 1972 to the present. First, during 1973-1982, the majority of African countries were classified as 'not free' (34 out of the 52 countries surveyed, or 65 per cent). Whilst a few in this group on occasion moved in or out of this category, others - such as Algeria, Angola, Benin, Burundi, Central African Republic, Chad, DRC, Equatorial Guinea, Guinea, Guinea Bissau, Libya, Malawi, Mali, Mauritania, Mozambique, Namibia, Niger, Somalia, Tanzania and Togo - did not improve at all. On the other hand, 15 (28,8 per cent) of the countries were classified as 'partly free', and only three countries (5,7 per cent) were classified as 'free' (these consisted of Botswana, except in 1973; The Gambia, except in 1982; and Mauritius, except in 1979, 1980 and 1981).

For the period 1991 to 2000, there was considerable improvement. The number of countries classified as 'not free' dropped to 21 (40 per cent) and those classified as 'party free' increased to 23 (43 per cent). However, the most dramatic increase was in the number of countries classified as 'free', which tripled to nine (17 per cent). A pattern begins to emerge with a group of countries that throughout this period were either classified as 'not free' (Cameroon, Chad, DRC, Equatorial Guinea, Libya, Mauritania, Rwanda, Somalia and Sudan);

27 It is worth noting that the reviews started as the Balance Sheet of Freedom in the 1950s.

28 This is explained in depth in Freedom in the World 2017, Methodology, https:// freedomhouse.org/report/methodology-freedom-world-2017 (accessed 30 June 2017). 
'partly free' (Central African Republic, Comoros, Gabon, Guinea Bissau, Lesotho, Madagascar, Morocco, Senegal and Zimbabwe) or 'free' (Benin, Botswana, Cape Verde, Mauritius, Namibia and São Tomé and Principe).

An analysis of the survey for the period 2007 to 2017 shows a decline in respect of political and civil rights on the continent. The number of countries classified as 'not free' increased marginally to 22 (41 per cent), and those classified as 'partly free' dropped to 22 (41 per cent), and the only improvement was that one more country joined the category of 'free' countries to raise them to 10 (18 per cent). The decline is also reflected in the quality of the performance of countries during this period. Almost the same group of countries were classified throughout this period as either 'not free' (Algeria, Angola, Cameroon, Chad, Congo Republic, DRC, Egypt, Equatorial Guinea, Eritrea, Rwanda, Somalia, South Sudan, Sudan and Swaziland); 'partly free' (Burkina Faso, Comoros, Kenya, Liberia, Madagascar, Malawi, Morocco, Mozambique, Niger, Nigeria, Seychelles, Tanzania, Togo and Zambia); or 'free' (Benin, Botswana, Cape Verde, Ghana, Mauritius, Namibia, São Tomé and Principe and South Africa). As in the previous period, in some countries there were a few movements during this period between the different levels of freedom of political and civil rights.

Second, the 2017 Freedom in the World report points out that 2017 marked the eleventh consecutive year in which global declines in political and civil rights outnumbered improvements. An analysis of the global tables reveals that although dramatic declines in freedom were experienced in every region in the world, the largest were in Africa. Of particular concern is the fact that six of the first 10 countries in the world that underwent the largest decline in the last 10 years are from Africa. ${ }^{29}$ Furthermore, of the 49 countries designated as 'not free', six African countries feature amongst the 11 countries with the worst aggregate scores for political and civil liberties. ${ }^{30}$ In fact, the 2017 report on Africa underlines the steady decline: Twenty-three countries (43 per cent) are designated as 'not free'; 21 (39 per cent) as 'partly free'; and 10 (18 per cent) as 'free'.

I now turn to the third global study, which focuses on the broader issue of state fragility.

29 These are Central African Republic; The Gambia; Mali; Burundi; Mauritania; and Ethiopia. See further A Puddington \& T Roylance 'Freedom in the World 2017. Populists and autocrats: The dual threat to global democracy' 5 https://freedom house.org/sites/default/files/FH_FIW_2017_Report_Final.pdf (accessed 30 June 2017).

30 Puddington \& Roylance (n 29 above) 6. These are Eritrea; South Sudan; Somalia; Sudan; Equatorial Guinea; and Central African Republic. 


\subsubsection{Evidence based on the Fragile States Index}

The Fragile States Index (formerly the Failed States Index) is an annual report produced since 2005 by the United States (US) Fund for Peace and the magazine Foreign Policy. ${ }^{31}$ The Index assesses states' vulnerability to conflict or collapse using 12 political, social and economic indicators and more than a hundred sub-indicators that seek to measure factors conducive to conflict. The project is premised on the belief that

it is critically important that the international community understand and closely monitor the conditions that contribute to fragility - and be prepared to take the necessary actions to deal with the underlying issues or otherwise mitigate the negative effects.

Many of these indicators - such as group grievance; uneven economic development; poverty and economic decline; state legitimacy; public services; factionalised elites; and human rights - raise issues relevant to the rule of law, as defined earlier. ${ }^{32}$

A study of the 10-year trend of the Fragile States Index provides some useful indications of the state of rule of law compliance in Africa. An analysis of the index for the period 2007-2016 shows that, almost throughout this entire period, 14 African countries featured amongst the 20 most vulnerable states in the world. There are no surprises as to who these are, as the countries include those that have experienced internal conflict and strife. ${ }^{33}$ In fact, seven of the eight countries in the 'very high alert' category are in Africa. ${ }^{34}$ However, the performance of some countries that have progressively worsened over the years deserves attention. It is noted that South Africa, long regarded after the end of apartheid in 1994 as the economic and political engine of Africa, has been demonstrating signs of significantly-worsening trends in line with deepening political divisions and social unease leading to regular service delivery protests and civil disturbances in the country. ${ }^{35}$ The 2016 report also points to 'significant worsening' of conditions in other African countries, such as Senegal, Guinea Bissau, Mozambique, Gambia, Djibouti and Ghana. The case of Ghana, which in the last two decades 'is often cited as a shining light of democracy and development in a frequently

31 See http://fundforpeace.org/fsi/ (accessed 30 June 2017).

32 Other indicators include demographic pressures; refugees and internally-displaced persons; human flight and brain drain; security apparatus; and external intervention. See http://library.fundforpeace.org/library/fragilestatesindex-2016. pdf 12-14 (accessed 30 June 2017).

33 These are South Sudan; Somalia; Central African Republic; Sudan; DRC; Chad; Guinea; Nigeria; Zimbabwe; Ethiopia; Guinea Bissau; Burundi; Eritrea; and Niger.

34 These are DRC; Chad; Sudan; Central African Republic; South Sudan; and Somalia. See http://library.fundforpeace.org/library/fragilestatesindex-2016.pdf (accessed 30 June 2017).

35 See $\mathrm{MH}$ Maserumule 'What rising protests in South Africa say about attitudes towards local government' ${ }^{\prime}$ https://mg.co.za/article/2016-06-21-what-risingprotests-in-south-africa-say-about-attitudes-towards-local-government (accessed 30 June 2017). 
conflicted region', has now reached the point of being a 'cause for alarm'. 36

Overall, what the Fragile States Index shows is that failing or critically weak states are concentrated in sub-Saharan Africa. Furthermore, most of the countries in the category of 'high' or 'very high alert' coincide with those noted by the World Justice Project and Freedom House surveys as consistently performing poorly with regard to respecting the basic norms of the rule of law.

Moving away from these global indicators of the state of adherence to the rule of law, I turn to a regional indicator.

\subsection{Evidence from a regional indicator: The Ibrahim Index of African Governance}

Since it was first published in 2007, the Ibrahim Index of African Governance (Ibrahim Index) has been providing an annual assessment of the quality of governance in every African country based on 90 indicators constituted into 14 sub-categories, four categories and one overall measurement of governance. ${ }^{37}$ The Ibrahim Index provides the most comprehensive data available on African governance. The four main categories guiding the assessment are safety and the rule of law; participation and human rights; sustainable economic opportunity; and human development. Like the surveys examined above, the Ibrahim Index, through its broad sub-categories and indicators, covers most of the factors identified earlier as critical components of the rule of law. This is particularly so with respect to its 14 sub-categories. ${ }^{38}$

The 2016 Ibrahim Index Report provides an overall governance report of all African countries for the decade from 2006 to 2015 and contains rich, useful information about trends not only in governance, but also in adherence to the rule of law. As the only comprehensive indigenous index on these issues, it needs to be taken seriously.

The 2015 rankings show that the top 10 performers were Mauritius, Botswana, Cape Verde, Seychelles, Namibia, South Africa, Tunisia, Ghana, Rwanda and Senegal. By contrast, the 10 most underperforming countries were Somalia, South Sudan, Central African Republic, Libya, Eritrea, Sudan, Chad, Equatorial Guinea, DRC

36 Maserumule (n 35 above) 18.

37 See Mo Ibrahim Foundation 'A decade of African governance 2006-2015: 2016 Ibrahim Index of African governance. Index Report' http://s.mo.ibrahim.foun dation/u/2016/10/01184917/2016-Index-Report.pdf?_ga=2.79825495.11095210 50.1496390149-1550746377.1489484030 (accessed 30 June 2017).

38 The 14 sub-categories consist of the following indicators: (i) under safety and rule of law: rule of law, accountability, personal safety and national security; (ii) under participation and human rights: participation, rights and gender; (iii) under sustainable economic opportunity: public management, business environment, infrastructure and rural sector; and (iv) under human development: welfare, education and health. 
and Angola. ${ }^{39}$ In the sub-category of rule of law, the top 10 performers are almost the same (Mauritius, South Africa, Botswana, Cape Verde, Ghana, Namibia, Senegal, Malawi, Zambia and Seychelles). Likewise, the weakest countries in adhering to the rule of law are nearly identical to the poorest performers in overall governance: Somalia, Eritrea, Libya, Central African Republic, South Sudan, Equatorial Guinea, Burundi, Guinea Bissau and Angola. 40

However, what is most revealing is the trend emerging from an analysis of the Ibrahim Index in the previous decade, namely, from 2006 to $2015 .{ }^{41}$ While the continental average score in overall governance during this period improved by one point, the category of safety and rule of law was the only category that registered a negative trend, falling by 2,8 score points. This decline was driven by negative results across all the four constituent sub-categories of safety and rule of law. In fact, the 2015 Index shows that almost two-thirds of African citizens live in a country where safety and the rule of law has deteriorated over the last ten years.

Moreover, a look at the 10 highest-scoring countries in terms of human rights shows that in six of these countries, over the past decade there has been deterioration regarding respect for rights. ${ }^{42}$ As a result, despite their overall good performance, a general review of the scoring for safety and the rule of law over the last decade shows that good performers, such as South Africa, registered the largest decline during this period, followed by Cape Verde, Botswana, Seychelles and Mauritius. It is also worth noting that two-thirds of the countries on the continent, representing 67 per cent of the population, have also shown deterioration in freedom of expression over the last decade. Overall, the 10-year country trend in the Ibrahim Index, which shows the most improved countries ${ }^{43}$ and the countries that have deteriorated the most during this period, ${ }^{44}$ presents a rather confusing, unsettled and unpredictable picture.

\subsection{Some tentative conclusions}

Although the above surveys provide a reasonably clear indication of the extent of the crisis of the rule of law in Africa, a number of caveats

39 Mo Ibrahim Foundation (n 37 above) 18.

40 Mo Ibrahim Foundation 34.

41 See Mo Ibrahim Foundation 2.

42 This is evident when considering significant deterioration since 2006 in four of the five underlying indicators, namely, civil liberties, freedom of association and assembly, human rights violations, and freedom of expression. See further Mo Ibrahim Foundation (n 37 above) 44.

43 These were Côte d'Ivoire; Togo; Zimbabwe; Liberia; Rwanda; Ethiopia; Niger; Morocco; Kenya; and Angola. See Mo Ibrahim Foundation (n 37 above) 19.

44 These were Libya; Madagascar; Eritrea; Central African Republic; Mali; The Gambia; Mauritania; Burundi; Ghana; and South Africa. It is important to note that South Sudan was not included in this 10-year analysis since there was no independent data on the country prior to 2011. See Mo Ibrahim Foundation (n 37 above) 19. 
should be borne in mind when interpreting and drawing conclusions from the findings. Two are particularly important.

First, many of the global surveys, such as Freedom House's Freedom in the World and Fragile States Index, have been criticised for their perceived bias towards Western positions, especially those favoured by the US. ${ }^{45}$ In spite of this, the use of several sources, particularly an African resource, such as the Ibrahim Index, could help correct the impact of such biases. Second, the impact of subjective contextual factors in assessing the different indicators is an important factor that could affect some of the results. This is so because the implementation of the various rule of law components is influenced by the judicial, historical, political, social or cultural context of each country. In other words, many of the surveys depend on responses to uniformly-formulated questions, but there is no reason to assume that the local context does not play a part in the responses. This makes it difficult to arrive at an accurate objective conclusion.

For example, in assessing the extent of judicial independence, account must be taken of the fact that judicial independence is not merely an ideal, but that there are differences in approach dictated by the differences in legal traditions. ${ }^{46}$ The same is true in assessing the standards of separation of powers in each country. This often depends on the particular tradition of separation of powers in question. Another example is the issue of corruption. Certain forms of corruption have become so endemic and routinised that in some countries citizens no longer consider this as corruption but rather as a normal way of 'getting things done'. This is illustrated by the public utterances of President Jacob Zuma of South Africa. He has argued that the National Prosecuting Authority was justified in abandoning more than 750 charges of corruption and racketeering against him because corruption is only a crime in a 'Western paradigm'. ${ }^{47}$ In rejecting allegations of impropriety for the use of state funds in upgrading his private residence under the pretext of enhancing his security protection, Zuma also argued that only 'very clever and bright people', and not ordinary South Africans, see anything wrong with this use of taxpayers' money. ${ }^{48}$

45 See 'Criticisms of Freedom House Methodology' http://www.zeepedia.com/ read.php?reports_criticisms_of_freedom_house_methodology_gross_national_hap piness_human_resource_development $\& b=32 \& c=22$ (accessed 30 June 2017).

46 Examples could be multiplied. Eg, different countries use different means and procedures to attain justice. In criminal proceedings, some countries may use the adversarial system, and others the inquisitorial system; some may use juries whereas others rely only on the judge; again, in some countries there is free legal aid but not in others.

47 See 'Zuma wanted charges dropped because corruption is a "Western thing"' http://www.news24.com/SouthAfrica/Politics/Zuma-wanted-charges-droppedbecause-corruption-is-a-Western-thing-20141012 (accessed 30 June 2017).

48 As if to prove Zuma correct, the ruling African National Congress (ANC) went on the win a majority of seats in the parliamentary elections at the peak of the Nkandla scandal, even though with a much reduced majority. See 'Zuma: 
Hence, the degree of adherence to, as well as the measurement of compliance with, the rule of law in the various countries is sometimes affected by the local context. Nevertheless, it is debatable whether taking into account such factors could explain significant differences in the level of respect for the rule of law. The combination of different sources, instruments and methods used by the different surveys provides a reasonable basis to draw important conclusions about the state of respect for the rule of law in Africa.

In correlating the conclusions arrived at by the different surveys, it is clear that the levels of respect for the rule of law in Africa vary from country to country. Some countries have performed well in all or some of the core elements identified above, either consistently or intermittently, while others have not. Three important conclusions may be drawn.

First, although the 1990s appeared to have ushered in a new commitment to respect for the rule of law, this seems to have peaked in the early 2000s and since then has gone into a steady decline. Whilst a cursory examination of the various surveys points to the increasing disregard of certain components of the rule of law, further studies are needed to identify exactly what these are.

Second, in spite of the impression of a degree of rule of law revival on the continent, all the surveys show that a number of countries have hardly made any progress at all since the 1990s. In fact, one could argue that at least 20 of Africa's 54 states are unable to provide even the barest minimum standards of the rule of law for their citizens. $^{49}$

Third, all the different surveys and indicators reveal that even countries such as Mauritius, Botswana, Namibia, South Africa, Cape Verde and, more recently, Ghana, Seychelles and Senegal, which are doing well, have been declining in their compliance with the basic standards of the rule of law. This has been alarming in the cases of countries such as South Africa and Ghana, suggesting that the crisis of the rule of law in Africa is not only profound but affects all countries on the continent. Nevertheless, one may argue that in the countries where the rule of law problem has been protracted and persistent, the problem is of a profound nature that goes right to the heart of the constitutional and political system in place. On the other hand, the problem in countries like South Africa and Ghana probably is a reflection of the careless use of law or the abuse of powers that is of a temporary nature and not systemic although, if left unchecked, such

Nkandla not an issue for ordinary voters' https://www.enca.com/elections-2014south-africa/zuma-nkandla-not-issue-ordinary-voters (accessed 30 June 2017).

49 In this group, one can distinguish between those that have seen little or no change since the 1990s, such as Angola; Cameroon; Burundi; Congo Republic; DRC; Guinea Bissau; Equatorial Guinea; Sudan; Libya; South Sudan; and Somalia, and others where there have been occasional periods of improvement, such as Central African Republic; Chad; The Gambia; Zimbabwe; Angola; Niger; Mauritania; Mozambique; and Mali. 
abuse runs the risk of becoming protracted: The former (careless use) may be described as constitutional capture and the other (abuse of powers) as constitutional mischief. Therefore, there is no room for complacency or for assuming that it can be dealt with only at national level. How can this crisis be dealt with?

\section{Addressing the crisis of the rule of law in Africa}

Apart from the Ibrahim Index, there is no other mechanism for monitoring and addressing the persistent threats caused by the nonimplementation and non-adherence to the rule of law in Africa. It is argued that there is a need for such a mechanism. Respect for the rule of law entails compliance with international standards of rule of law as laid down in international as well as regional and sub-regional instruments. As noted earlier, the AU, through its Constitutive Act, and the African Democracy Charter both provide for the respect for the rule of law by African countries. Besides this, the AU's Agenda 2063 lists as one of its aspirational goals that Africa will 'be a continent where democratic values, culture, practices, universal principles of human rights, gender equality, justice and the rule of law are entrenched' ${ }^{50}$ It has been noted that all African countries have in one way or another entrenched various components of the rule of law in their constitutions. Although this may have improved compliance levels in the early 1990s, the recent trend in the last two decades shows that constitutional entrenchment on its own will not suffice.

The $A U$ has a responsibility to ensure that the fundamental values and principles on which the organisation is founded, one of which is the rule of law, and which is inextricably linked with democracy, respect for human rights and constitutionalism, are respected. Compliance with the rule of law at national level is critical to the AU achieving this aspiration. From this perspective, it is argued that it is necessary for the $A U$ to take the lead in setting up measurement systems and for countries to develop their own abilities to monitor progress and identify areas of weaknesses that need to be corrected. In this regard, it is necessary to examine briefly what the AU has been doing, and to assess the weaknesses and strengths thereof to establish whether any lessons could be learnt from the approaches adopted to deal with rule of law issues by the European Union (EU) and the Council of Europe.

\subsection{Mechanisms for addressing Africa's rule of law challenges}

In the course of the transformation of the Organisation of African Unity (OAU) into the AU, the Heads of State and Government of the $\mathrm{AU}$ clearly committed themselves in the strongest possible terms to promote democracy, good governance and the rule of law amongst 
member states. This was against the backdrop of two decades of oneparty and military dictatorship that had stifled economic development and had led to political instability, civil strife, wars, unemployment, poverty and other ills. The importance of the rule of law is underscored in the various $\mathrm{AU}$ documents that have been adopted since it came into existence. In particular, the 2063 African Development Agenda, as pointed out above, in its aspiration 3, reiterates the dream of implementing good governance, respect for human rights, justice and the rule of law. This vision is driven by a realisation that the rule of law is the only way to stabilise conditions and relations within and between African countries and to provide an appropriate environment for constitutionalism, democracy and respect for human rights to take root and flourish.

The preceding analysis has shown that the AU agenda has not worked. What is worse, the optimism of the 1990s was short-lived. While the situation today may be relatively better than it was before the 1990s, the fact that respect for the rule of law is declining is a major cause for concern. All the results from most of the existing monitoring bodies on either the rule of law or any of its component parts paint a gloomy picture. No country on the continent is immune from this rule of law crisis. There are doubts about whether the AU has made a sufficient effort to deal with the present-day challenges to the rule of law that threaten to undermine the few gains of the post-1990 third wave of democratisation and its ensuing constitutional reforms. The AU's continuing credibility depends on how it deals with these issues.

It may be argued that, given what has occurred in the last two decades, the AU's normative foundation for monitoring and enforcing the rule of law is weak. There seems to be no clear strategy or mechanism provided in any of its instruments for monitoring compliance with or promoting the enforcement of and sanctioning for non-compliance with the rule of law, in general, or any of its critical components, in particular. The crisis of the rule of law on the continent arguably is a reflection of this lacuna. The presumption that recognising the rule of law and other fundamental principles in $\mathrm{AU}$ instruments and in national constitutions will solve the problem has not worked. Aspirations that are not matched by clearly-defined strategies to attain these end up as printed futility. The best strategy for dealing with rule of law problems, especially when they are as serious and persistent as they are in Africa, is the double-prong approach. This consists of developing and putting in place strong monitoring mechanisms and then backing them up with mechanisms for promoting enforcement where problems or possible problems are identified. If this were to be adopted by the $A U$, the question is whether it would require adopting new instruments or conventions or whether this could be accomplished within the existing normative framework of the organisation. 
Ideally, in order for the AU to intervene timeously and effectively, it needs a sound normative basis. As pointed out earlier, the present legal framework is rather weak. Whilst a reform of the existing treaties, such as the Constitutive Act of the organisation, will provide the best possible way forward as well as provide legitimacy for AU intervention, this certainly is not a realistic possibility. For one thing, drafting new treaties or amending existing treaties is a slow and cumbersome process. Even if a new instrument were to be adopted, the problem will remain of ratification and effective domestication. Too many AU instruments are languishing in a miserable twilight zone between ratification and effective domestication to warrant attempts to add yet another instrument to this category. Furthermore, it is very easy for the non-complying member states, who make up as much as onethird of the membership, to block any reforms. The important preoccupation today should be to establish how the AU can make the existing legal framework work more effectively.

The first challenge to deal with in this regard is that of devising better strategies to monitor compliance with the existing $A U$ standards and values of the rule of law by member states. How can this best be enhanced? Setting up new oversight mechanisms will certainly enhance the AU's rule of law credibility, but this is not likely to happen in the short or even long term. Therefore, it is better to explore how existing opportunities could best be exploited. In this respect, three organs of the $A U$ could play a role in monitoring rule of law compliance amongst member states, namely, the AU Commission's Peace and Security Council (PSC) and African Peer Review Mechanism (APRM), which has now become an organ of the $\mathrm{AU}$.

The AU Commission, provided for under article 20 of the Constitutive Act, has broad powers which include the power to 'initiate proposals for consideration by other organs'; the power to 'co-ordinate and monitor the implementation of the decisions' of the $\mathrm{AU}$; and the power to 'ensure the promotion of peace, democracy, security and stability'. ${ }^{51}$ One of its eight portfolios dealing with political affairs covers several components of the rule of law: human rights; democracy; good governance; electoral institutions; civil society organisations; humanitarian affairs and refugees; returnees; and internally-displaced persons. The AU Commission, therefore, has the potential to monitor rule of law compliance and does this to some extent by working closely with the PSC.

Articles 5 and 20 of the Constitutive Act were amended in 2003 to provide for the PSC. The Protocol Relating to the Establishment of the Peace and Security Council of the AU of 2002 gives it broad powers, to 'promote and encourage democratic practices, good governance

51 See arts 2(a), (g) and (r), respectively, of the Statutes of the Commission of the AU, ASS/AU/2(1)-d, http://www.au2002.gov.za/docs/summit_council/statutes.pdf (accessed 30 june 2017). 
and the rule of law, protect human rights and fundamental freedoms, respect for the sanctity of human life and international humanitarian law, as part of efforts for preventing conflicts'. Article 4(c) states that the PSC shall be guided by the principles enshrined in the Constitutive Act, the Charter of the United Nations and the Universal Declaration of Human Rights, particularly by 'respect for the rule of law, fundamental human rights and freedoms, the sanctity of human life and international humanitarian law'. ${ }^{52}$

The PSC was established as a collective security and 'early-warning' body with the ability to facilitate timely and efficient responses to conflict and crisis situations. It meets in continuous session and all its members are required to keep a permanent presence at the AU headquarters. The Protocol gives it considerable powers to monitor the compliance by member states with the rule of law values and principles contained in the AU Constitutive Act and other instruments. It also has the power under article 8(5) of the Protocol to establish subsidiary bodies and seek such military, legal and other forms of expertise that it may require. On the basis of this mandate, it established a Committee of Experts to assist it to elaborate on its draft decisions. A Continental Early Warning System (CEWS) was established under article 12 of the Protocol to 'facilitate the anticipation and prevention of conflicts'. It is part of the African Peace and Security Architecture (APSA), ${ }^{53}$ the AU's key instrument for promoting peace, security and stability in Africa. The CEWS gathers information about potential conflicts or threats to the peace and security of member states and submits reports to the PSC and the Chairperson of the AU Commission. This is done by collecting, analysing and disseminating early-warning data on current and potential conflicts; preparing policy advice; and supporting political, civilian and military missions. A Panel of the Wise, established under article 11 of the Protocol, supports the PSC and the Chairperson of the $\mathrm{AU}$ in the promotion and maintenance of peace, security and stability in Africa, and is also a key component of the APSA. In 2010, the Panel's capacity was enhanced by the establishment of a team, called the Friends of the Panel of the Wise, consisting of five to 10 eminent African personalities. Their task is to support the Panel in its activities, such as fact-finding missions, engagement in formal negotiations and follow-up on recommendations. This was followed by the establishment of the Pan-African Network of the Wise (Pan Wise) in 2013, the objective of which is to strengthen, co-ordinate

52 Art 5(2) of the PSC Protocol lists criteria for members, including contribution to the promotion and maintenance of peace and security in Africa; participation in conflict resolution, peace-making and peace-building at regional and continental levels; the willingness and ability to take up responsibility for regional and continental conflict resolution initiatives; a contribution to the Peace Fund and/or Special Fund; respect for constitutional governance, the rule of law and human rights; and commitment to AU financial obligations.

53 See http://www.peaceau.org/en/topic/the-african-peace-and-security-architecture -apsa (accessed 30 June 2017). 
and harmonise prevention and peace-making efforts in Africa under a single umbrella.

With these broad powers, and the numerous expert committees for supporting it, the PSC therefore has the potential to be an effective body for monitoring numerous issues concerning the violation of the rule of law in a particular country or generally. However, in spite of these powers, its ability to act effectively is limited by the potential for political interference. This is manifested in several ways. For example, although article 5(2) of the Protocol requires that only representatives from states with a good record in, inter alia, good governance, respect for the rule of law and human rights, are elected as members, in reality political calculations trump all else. The same applies to appointments to the various committees, where political considerations are often given priority over technical competence. At the end of the day, many of the states that have for the last three decades maintained the worst continental record regarding compliance with the rule of law have been elected to sit on the $\mathrm{PSC}^{54}$ or allowed to appoint members to the committees. Although the operating rules of the PSC provide that the inclusion of any item on the provisional agenda may not be opposed by a member state, the fact that so many states with a bad record of governance are members makes it easy for effective action to be blocked. ${ }^{55}$

The other body that deserves mention here is the APRM. This was established in 2003 by the New Partnership for Africa (NEPAD) Heads of State and Government Implementation Committee (HSGIC) as an instrument for monitoring the performance in governance amongst member states. The APRM was an independent self-monitoring body the membership of which was voluntary. However, in 2014 it was integrated into the AU system. The primary objective of the APRM is to foster the adoption of policies, values, standards and practices of political and economic governance that lead to political stability, accelerated sub-regional and continental economic integration, economic growth and sustainable development. Member states that join the APRM undertake to voluntarily and independently review their compliance with African and international governance commitments. Their performance and progress are measured in four thematic areas, namely, democracy and political governance; economic governance and management; corporate governance; and socio-economic development. It is the review in the area of

54 See, eg, Angola (2012-2014); Burundi (2008-2012); Cameroon (2004-2008 and 2012-2014); DRC (2004-2008 and 2012-2014); Egypt (2006-2008 and 20122014); Equatorial Guinea (2010-2013); Gabon (2004-2010); The Gambia (20122014); Libya (2004-2006 and 2010-2013); Mauritania (2010-2012); Rwanda (2006-2012); Sudan (2004-2006); Swaziland (2008-2010); and Zimbabwe (20102013).

$55 \mathrm{Eg}, 10$ of the 14 members of the first PSC consisted of states most of whom had the dubious reputation of having the worst record regarding rule of law compliance on the continent (Algeria; Cameroon; DRC; Ethiopia; Gabon; Kenya; Libya; Mozambique; Sudan; and Togo). 
democracy and democratic governance, which includes several areas critical to the rule of law, such as the executive, legislative and judicial branches of government, civil society and the media. ${ }^{56}$ Although reviews are carried out within 18 months of a member state joining the APRM and thereafter every two to four years, the APRM can commission a review at the request of participating Heads of State and Government if there are signs of a political and economic crisis. A national programme of action for the state concerned to address problems identified is prepared after each review. A monitoring body prepares an annual report on progress in implementing the programme of action for the APRM Forum of Heads of State and Government.

It is fair to say that besides the Ibrahim Index, the APRM perhaps is the most comprehensive attempt by African governments to monitor and promote good governance and, in this way, also monitor compliance with many aspects of the rule of law. Although the APRM is now integrated into the $A U$, there is insufficient commitment and political will at the highest level to enable it to make the impact it could on governance in general and the rule of law, for that matter. First, only $35 \mathrm{AU}$ members (that is, 65 per cent of AU members) have joined the APRM by signing its Memorandum of Understanding. After more than 10 years of its existence, only 17 of these countries have completed their self-assessments and been peer-reviewed by the Forum. It is not clear why the others have not been peer-reviewed. Second, countries are not bound to implement the APRM recommendations; they may even reject some of these as inappropriate. The reports have more moral value than any sort of coercive value. It is thus not surprising that in spite of the fact that some of the continent's most egregious rule of law violators (such as Algeria, Cameroon, Ethiopia, Mozambique and Rwanda) have been reviewed and given important recommendations to improve their performance, this has had hardly any impact on their behaviour, thus calling into question the vast amounts of taxpayer money spent on the review process. Third, the APRM's lack of adequate resources, along with its continual vulnerability to political interference by states, has weakened its ability to act as an effective independent monitoring body.

Nevertheless, the potential positive impact the APRM can have in monitoring and influencing rule of law change in African countries cannot be ignored. Its critical role as an early warning system was

56 There are nine key objectives in this thematic area. These include the prevention and reduction of intra- and inter-country conflicts in constitutional democracy; promoting periodic political competition and opportunity for choice, the rule of law, a bill of rights and supremacy of the constitution; upholding of the separation of powers; protecting judicial independence; ensuring an effective and accountable parliament as well as accountable, efficient and effective public office holders; the fight against corruption in the political sphere; the promotion and protection of the rights of women, children and young persons and vulnerable groups, including displaced persons and refugees. 
underscored in 2007 when its reports warned the continent's leaders of the xenophobic violence brewing in South Africa and Kenya. Nothing was done, and the ensuing attacks and loss of life and property in these countries during 2008 and 2007/2008, respectively, were a wake-up call for African leaders. However, it is uncertain whether any lessons were learnt from this experience. This is so not only because of the steady continental decline in rule of law standards, but also because of the fact that even more violent, and equally fatal, xenophobic attacks again erupted in South Africa in 2015.

To turn now to the issue of enforcement of rule of law standards and values, the literature shows that many approaches are possible. ${ }^{57}$ Within the framework of the AU, pressure is often brought to bear on member states to comply with their rule of law commitments in two main areas, namely, human rights and democratic governance. In both areas, its judicial and quasi-judicial institutions, as well as those of its regional economic communities, have been quite active.

The most widely-known quasi-judicial body is the African Commission on Human and Peoples' Rights (African Commission), provided for in the African Charter on Human and Peoples' Rights of 1981 (African Charter). Established under article 30 of the African Charter, the African Commission is charged with the promotion of human and peoples' rights and ensuring their protection. ${ }^{58}$ The Commission has been co-operating with other human rights institutions (inter-governmental or non-governmental) in many areas relating to the promotion and protection of human rights. It has also appointed Special Rapporteurs on Prisons and Other Places of Detention in Africa; on Arbitrary, Summary and Extra-Judicial Executions; and on Human Rights of Women in Africa to research, gather and document information in these areas for use by the African Commission in formulating advice to African states.

The protective mandate of the African Commission requires it to take measures to ensure that citizens enjoy the rights contained in the African Charter. This entails ensuring that states do not violate these rights and that when they do, the victims are reinstated in their rights. To achieve this, the African Commission has instituted a complaints system through which an individual, an NGO or group of individuals who feel that their rights or those of others have been or are being violated, can petition to the Commission about these violations. ${ }^{59}$ Over the years, the Commission has received and reviewed numerous

57 In the context of the EU, see C Closa \& D Koschenov (eds) Reinforcing rule of law oversight in the European Union (2016).

58 Art 45 of the Human Rights Charter enumerates the functions of the Commission as (i) the promotion of human and peoples' rights; (ii) the protection of human and peoples' rights; (iii) the interpretation of the provisions of the Human Rights Charter; and (iv) any other task assigned to it by the AU Assembly.

59 A petition could also be made by a state party to the Charter which reasonably believes that another state party has violated any of the provisions of the Charter. 
complaints and made recommendations to the states concerned and the AU. ${ }^{60}$ The Commission also sends missions to several state parties to investigate allegations of serious human rights violations, to make recommendations to the state concerned to improve the situation. As part of its protective mandate, the African Commission also receives and considers periodic reports submitted by state parties in conformity with article 62 of the African Charter. In addition, article 45(3) of the African Charter mandates the African Commission to interpret the provisions of the Charter. Based on this provision, the Commission has adopted resolutions clarifying ambiguous provisions in the African Charter. ${ }^{61}$

The judicial organ of the AU is the African Court on Human and Peoples' Rights (African Court), which was established to complement and reinforce the African Commission. ${ }^{62}$ The ability of this Court to play a significant role in the enforcement of the rule of law in Africa is influenced by two factors. First, its jurisdiction is extended to disputes concerning the interpretation and application of the African Charter and any other relevant human rights instruments ratified by the states concerned. Second, individuals and NGOs can bring matters before the Court only if the state concerned has made a special declaration under article 34(6) recognising the competence of the Court to receive such cases. As of May 2017, only eight of the 30 state parties to the Protocol to the African Charter on Human and Peoples' Rights on the Establishment of an African Court on Human and Peoples' Rights (African Court Protocol) had made this declaration. ${ }^{63}$ It is worth noting some of the continent's good performers in respect of rule of law compliance, such as Botswana, Cape Verde, Namibia and Seychelles, are not parties to this Protocol. Some of the equally highlyrated countries, such as Mauritius and South Africa, have not made

60 Most of these decisions have been published in the series African Human Rights Law Reports, published annually by the Pretoria University Law Press (PULP) since 2003. The series is available at http://www.pulp.up.ac.za/catalogue (accessed 30 June 2017).

61 Examples of these are the Resolution on Electoral Process and Participatory Governance (1996); the Resolution on Granting Observer Status to National Human Rights Institutions in Africa (1998); the Dakar Declaration and Recommendations on the Right to Fair Trial (1999); the Resolution Urging the States to Envisage a Moratorium on the Death Penalty (1999); the Resolution on the HIV/AIDS Pandemic - Threat against Human Rights and Humanity (2001); the Declaration of Principles on Freedom of Expression in Africa (2002); the Resolution on Guidelines and Measures for the Prohibition and Prevention of Torture, Cruel, Inhuman or Degrading Treatment or Punishment in Africa (Robben Island Guidelines on Torture); and the Principles and Guidelines on the Right to a Fair Trial and Legal Assistance in Africa (2003). See generally C Heyns \& M Killander (eds) Compendium of key human rights documents of the African Union (2013) 359.

62 The Court was established by virtue of art 1 of the Protocol to the African Charter on Human and Peoples' Rights on the Establishment of an African Court on Human and Peoples' Rights, 1998, which entered into force on 25 January 2004, http://www.achpr.org/files/instruments/court-establishment/ achpr_instr_proto_court_eng.pdf (accessed 30 June 2017).

63 These are Benin; Burkina Faso; Côte d'Ivoire; Ghana; Mali; Malawi; Tanzania; and Tunisia. 
the article 34(6) declaration. Therefore, it is unlikely that the African Court will have the same impact that the African Commission has had, especially when dealing with human rights violations involving individuals.

Apart from the AU's judicial and quasi-judicial institutions, most of its other organs, such as the AU Commission, the PSC and the PanAfrican Parliament, often intervene in one way or another when violations of the rule of law threaten peace and security within, and sometimes between, member states. The African Democracy Charter is perhaps the most comprehensive AU legal instrument covering several aspects of the rule of law. This Charter promotes good governance by advocating democracy, the rule of law and human rights, and providing sanctions in cases of unconstitutional changes of government. The Democracy Charter basically consolidates in one instrument a number of other previous instruments and declarations designed to promote good governance, constitutionalism and the rule of law, and backs this up with a system of sanctions. Although the African Democracy Charter has significantly reduced the incidences of unconstitutional changes of government in Africa and the resulting rule of law violations associated with these, its effectiveness has been limited by a lack of political will to enforce it consistently in every situation where the Democracy Charter has been violated. As a result, it has not had the impact it could have had in promoting good governance, constitutionalism, respect for the rule of law, and human rights. 64

More generally, the RECs $s^{65}$ have also been involved in dealing with crises provoked by violations of one or another aspect of the rule of law in member states. In addition, numerous international nongovernmental institutions in Africa play an important role in the enforcement of the rule of law. ${ }^{66}$ These bodies in their different ways intervene to investigate serious cases of systemic violations of the rule of law, and issue statements or recommendations that can bring pressure to bear on governments to change their policies.

Nevertheless, it is not surprising that in spite of all the numerous instruments mentioned above, the rule of law situation in Africa

64 See generally S Saungweme 'A critical look at the Charter on Democracy, Elections and Governance in Africa' http://www.sarpn.org/documents/d0002566/ Charter_Saungweme_May2007.pdf (accessed 30 June 2017); PJ Glen 'Institutionalising democracy in Africa: A comment on the African Charter on Democracy, Elections and Governance' (2012) 5 African Journal of Legal Studies 149.

65 The main RECs are the Economic Community of West African States (ECOWAS); the East African Community (EAC); the West African Economic and Monetary Union (UEMOA); the Southern African Development Community (SADC); the Intergovernmental Authority on Development (IGAD); and the Arab Maghreb Union.

66 See, eg, the African Election Authorities; the Anti-Corruption and Economic Malpractice Observatory; Corruption Watch; the African Bar Association; the African Association of International Law; the East African Magistrates and Judges' Association; and the Conference of Constitutional Jurisdictions of Africa (CCJA). 
remains precarious. The $A U$ and the RECs must do more than what they have done. Once they do so, are there any lessons to be learnt from Europe, particularly considering the fact that the design of the $\mathrm{AU}$ was influenced by that of the EU?

\subsection{Learning from the Council of Europe and the European Union}

Europe has two important institutional frameworks for dealing with rule of law issues, one focused on monitoring and reporting, the other on enforcement. Most of the existing mechanisms focus on the former rather than the latter. The main gaps today involve enforcement mechanisms because of the need to promptly intervene and prevent certain types of rule of law crises from degenerating into generalised civil strife.

\subsubsection{Council of Europe framework for monitoring the rule of law}

In March 2016, the European Commission for Democracy Through Law, commonly known as the Venice Commission, adopted the Rule of Law Checklist. The checklist provides a tool for assessing the rule of law in a given country from the viewpoint of its constitutional and legal structures, the legislation in force and the existing case law. The objective is to provide an objective, thorough, transparent and equal assessment of the state of the rule of law in a country.

The checklist is meant to be used by a variety of actors that may decide to carry out a rule of law assessment. These can include parliaments, state institutions, civil society organisations, international and regional organisations. Assessments have to take into account the entire context, consider which parameters have been met and to what extent, as well as other similar factors. Although the checklist covers what are regarded as the core elements of the rule of law, it is not exhaustive and is bound to change with time as new issues arise or old issues have to be redefined to meet changing circumstances.

The benchmarks against which the rule of law must be monitored and assessed under the Venice Commission rule of law checklist consist of the following:

(i) legality;

(ii) legal certainty;

(iii) the prevention of abuse (misuse) of powers; whether there are legal safeguards against arbitrariness and abuse of power (détournement de pouvoir) by public authorities;

(iv) equality before the law and non-discrimination;

(v) access to justice; and

(vi) examples of particular challenges to the rule of law.

The Venice Commission cannot initiate a rule of law assessment in any country. It acts only when it is requested to do so and will use the checklist to prepare its opinion. It may be asked to carry out a rule of 
law assessment by the EU Commission, which may use this as one of the reports to guide its intervention to enforce the EU values and principles on the rule of law in a member state.

\subsubsection{European Union framework for enforcing the rule of law}

With respect to the EU, article 4 of the Treaty on European Union (EU Treaty) states that the EU is founded on fundamental values, including the rule of law, democracy and fundamental rights. The EU Parliament in July 2013 requested that 'member states be regularly assessed on their continued compliance with the fundamental values of the Union and the requirement of democracy and the rule of law'. ${ }^{67}$ In March 2014, in response to a number of 'crisis events' in some member states which suggested that there were 'systemic threats to the rule of law', the EU Commission adopted a new EU framework to strengthen the rule of law. It also established a rule of law dialogue to be held each year among member states to promote and safeguard the rule of law within the EU.

The EU framework is designed to address and resolve a situation where there is a systemic threat to the rule of law. As such, it precedes and complements more specific action that is provided for under article 7 of the EU Treaty. Article 7 aims to ensure that all EU countries respect the common values of the EU, including the rule of law. The preventive mechanism of article $7(1)$ can be activated only in case of a 'clear risk of a serious breach', and the sanctioning mechanism of article 7(2) only in case of a 'serious and persistent breach by a member state' of the values set out in article 2 . The preventive mechanism allows the Council to issue a warning to the EU country concerned before a 'serious breach' actually has materialised. The sanctioning mechanism allows the Council to suspend certain rights deriving from the application of the treaties to the EU country in question, including the voting rights of that country in the Council. In this case, the 'serious breach' must have persisted for some time.

Since 2009, the EU Commission has on several occasions been confronted with crisis events in some EU countries that revealed specific rule of law problems. The Commission has addressed these events by exerting political pressure as well as launching infringement proceedings in case of violations of EU law. The preventive and sanctioning mechanisms of article 7 have so far not been applied. All EU institutions have a complementary role to play in promoting and maintaining the rule of law in the EU. The European Parliament has also on several occasions called for EU countries to be regularly assessed in terms of their continued compliance with the fundamental

67 See 'Communication from the Commission to the European Parliament and the Council. A new EU framework to strengthen the rule of law' 3, http:// ec.europa.eu/justice/effective-justice/files/com_2014_158_en.pdf (accessed 30 June 2017). 
values of the EU and the requirement of democracy and the rule of law.

Because the thresholds for activating both mechanisms of article 7 are very high, thereby underlining that the nature of these mechanisms is to be a last resort, they have not been able to respond quickly to threats to the rule of law in member states. ${ }^{68}$ The New EU Framework to Strengthen the Rule of Law was developed to provide clarity and enhance predictability as to the actions that the EU Commission may be called upon to take in future. The Framework is supposed to be activated where the authorities of a member state are taking measures or are tolerating situations which are likely to systematically and adversely affect the integrity, stability or proper functioning of institutions, and where safeguard mechanisms established at national level to secure the rule of law are not working. It is not designed to deal with individual breaches of fundamental rights or a miscarriage or miscarriages of justice, which should be dealt with by the national judicial system. The main purpose of the Framework is to address threats to the rule of law which are of a systemic nature. For example, if the political, institutional and/or legal order of a member state, such as its constitutional structure, separation of powers, the independence or impartiality of the judiciary or its system of judicial review, are threatened by new measures or other practices adopted by the public authorities without possibilities for domestic redress, then the Framework will need to be activated.

The framework for addressing systemic threats to the rule of law is based on four principles which guide the action that the Commission will take. These are:

(i) finding a solution through dialogue with the member state concerned;

(ii) ensuring an objective and thorough assessment of the situation at stake;

(iii) respecting the principle of equal treatment of member states; and

(iv) indicating swift and concrete actions to address the systemic threat and to avoid the use of article 7.

The process itself is composed of at least three stages: a Commission assessment; a Commission recommendation; and a follow-up to the recommendation. The Commission usually starts by collecting and examining all relevant information from diverse sources to determine whether there indeed is a clear indication of a systemic threat to the rule of law. If it considers this indeed to be the case, it will issue a 'rule

68 The art 7 mechanism that can be triggered by the Commission, the European Parliament and one-third of the member states has not always been suited to swift and effective intervention, more specifically those situations that do not fall under the scope of EU law and cannot be said to meet the threshold of art 7 but which do raise concerns regarding respect for the rule of law in a particular member state. 
of law opinion' to the member state concerned substantiating its concerns and giving it the opportunity to respond. In line with the 'duty of sincere co-operation' set out in article 4(3) of the EU Treaty, member states are expected to co-operate in the process and avoid any obstruction. During this phase, the Commission may also seek external expertise, the main purpose of which is to provide a comparative analysis of existing rules and practices in other member states. 69

If the matter is not satisfactorily resolved during the first stage, the Commission during the next stage will issue a 'rule of law recommendation' to the member state if it finds that there is objective evidence of a systemic threat and that the authorities are not taking appropriate action to address it. These recommendations will be guided by the dialogue with the member state and will include specific indications of ways and measures that need to be taken.

The final stage consists of a follow-up to the Commission's recommendations. This basically involves monitoring to see, for example, if some of the practices that have raised concerns continue to occur, or how the state implements the commitments needed to resolve the situation. If there is no satisfactory follow-up to the recommendations within the time limits set, the Commission may then activate one of the mechanisms set out in article 7.

As a rule and in appropriate cases, the Commission may seek the advice of the Council of Europe and its Venice Commission, and will co-ordinate its analysis with them in all cases where the matter is also under their consideration and analysis. In many respects, the Council of Europe and the Venice Commission complement each other in monitoring and enforcing the rule of law in Europe.

The question is whether, given the gravity of its rule of law crisis, Africa can learn from what is presently occurring in Europe.

\section{Conclusion}

Africa is experiencing a period of great turmoil and political uncertainty. The euphoria of the 1990s reminds us almost of independence ecstasy of the 1960s. The major lesson that can be learned is that the rule of law is as fragile in Africa today as it was at independence in the 1960s. This is holding back the continent's progress, and remains the biggest developmental challenge for the future. Because of the acute rule of law deficit, there is no enabling environment to attract the levels of investment that are needed to

69 The Commission may also decide to seek advice and assistance from members of the judicial networks in the EU, such as the networks of the presidents of Supreme Courts of the EU and the Association of the Councils of State and Supreme Administrative Jurisdictions of the EU. 
revive the continent's depressed economies and sustain economic growth.

At the normative level, while impressive steps have been taken at national and regional levels to entrench a culture of respect for the rule of law in Africa, an overview of the trend in the last three decades in the 54 countries on the continent, using several survey indicators and diverse sources of data, shows a steady and disturbing decline in adherence to the rule of law. The cause for alarm is not merely due to the continuous nature of this decline, but also because of the fact that it now affects not only countries well noted for their poor governance record, but also those that for decades have been known for their excellent governance and rule of law records, such as Botswana, Mauritius and Cape Verde and, more recently, Ghana, Namibia and South Africa.

An analysis of the performance of African countries suggests that there are not enough tools available at national and regional levels to deal with the rule of law crisis. How else can the fact be explained that, in spite of considerable efforts over the last few decades to ensure alternation of power and the adoption of the African Democracy Charter, more than 30 per cent of the continent's leaders have been in power for more than 10 years, and that in many of these countries their presidents operate more or less outside national laws and constitutions? ${ }^{70}$ Indeed, democracy and elections have been used, particularly in the last two decades, to distort and undermine the rule of law. To address the problems posed by the deteriorating rule of law situation, it is suggested that a number of measures should be taken.

First, the $A U$ and the RECs must take the lead to ensure that African countries are run by leaders guided by the rule of law and not by soldiers and strongmen guided by their unpredictable impulses - in other words, that Africa is governed by the rule of law and not by the rule by law imposed by dubious majorities. As a global ideal and because of the high level of interdependency, which means that a violation of many of the core elements of the rule of law in one country, especially, was continuous and systemic, is bound to have adverse effects on other states, a collective monitoring and enforcement strategy within the institutional framework of the AU and the RECs is imperative. For example, the forces of bigotry, populism, racism and xenophobia which are on the rise in countries such as

70 The current list of the longest-serving presidents is as follows: Teodoro Obiang Nguema Mbasogo of Equatorial Guinea (38 years); Jose Eduardo Dos Santos of Angola (38 years); Paul Biya of Cameroon (35 years); Yoweri Museveni of Uganda (31 years); Omar Al-Bashir of Sudan (28 years); Idriss Deby of Chad (27 years); Isaias Afwerki of Eritrea (24 years); Denis Sassou Nguesso of Republic of Congo (20 years; but if a previous stint from 1979 to 1992 is included it becomes 34 years); Addelaziz Bouteflika of Algeria (18 years); Ismail Omar Guelleh of Djibouti (18 years); Paul Kagame of Rwanda (17 years); Joseph Kabila of DRC (16 years); Faure Gnassingbe of Togo (12 years); and Pierre Nkurunziza of Burundi (11 years). 
South Africa can have far-reaching consequences for other countries in the Southern African region and beyond. A co-ordinated collective effort by states both within the AU and the RECs stands a better chance of exerting peer pressure for more effective corrective action to be taken.

Second, it is vital for the continent to acquire its own measurement systems and for countries to develop their own strategies to gather and use robust and reliable data to regularly monitor progress in the implementation of the various components of the rule of law in order to identify and deal with problem areas. Addressing the continent's deep-rooted and systemic rule of law failures calls for a state of permanent vigilance and more proactive measures than those that have so far been taken by the AU. The EU framework for enforcing the rule of law provides many workable options which the AU Commission can adopt and implement without the need for amending any existing instrument or even adopting a new instrument.

Finally, there is no urgent need for new monitoring or enforcement mechanisms in either the AU or its RECs. What evidently is needed, however, is a genuine and serious commitment by the AU Commission and the other institutions to fully implement the existing instruments, particularly the African Democracy Charter. If the African Commission had discharged the responsibilities conferred on it by article 44(2)(a), which states that '[t]he Commission shall develop benchmarks for the implementation of the commitments and principles of this Charter and evaluate compliance by state parties', 71 this would have gone a long way towards exerting pressure on states to implement the numerous components of the rule of law provided for in the African Democracy Charter.

The African Commission's mandate is very clear: Implementing this mandate does not require the approval of member states, although the Commission is required, as with all its other activities, to report to the political bodies of the AU. Its failure to initiate the implementation of the compliance mechanisms in chapter 10 of the African Democracy Charter therefore is inexplicable. This lack of administrative will to implement the Democracy Charter has contributed considerably to the failure of this very progressive instrument to take effect and contribute to entrenching democracy, good governance, respect for the rule of law and human rights on the continent. One may argue that the failure of the AU Commission to discharge its rule of law mandate under the Democracy Charter probably is one of the predictable consequences of having too many illiberal member states whose citizens work in the organisation's numerous institutions. Individuals from such states are unlikely to promote progressive ideas and policies within the $A U$ and its structures. Thus, the continuous disrespect for the rule of law in so

71 My emphasis. 
many $A U$ member states may in this indirect manner have a negative impact upon the citizens of other member states.

In the final analysis, there is no denying that the current state of the rule of law in Africa calls for urgent and decisive intervention. Intervention by the $\mathrm{AU}$ and its RECs within their existing treaty frameworks is a viable option that needs to be explored. In so doing, it is imperative to adopt the two-prong approach of, in the first place, encouraging monitoring through routine, continuous and systematic collection and analysis of information about the state of adherence to the rule of law and, in the second place, using this information to develop strategies to promote the enforcement of rule of law principles, values and standards. 